\title{
Characteristics of Thai Women Entrepreneurs: A Case Study of SMEs Operating in Lampang Municipality Area
}

\author{
Reema Thakur, John Walsh* \\ Shinawatra University, Bangkok, Thailand \\ *jcwalsh100@hotmail.com
}

\begin{abstract}
Thai female entrepreneurs often establish entrepreneurial ventures as time-sensitive operations that are not necessarily intended to be the principal income generators for a household but act as supplementary sources of income. Such ventures might also provide other secondary benefits, including occupation for migrant women with no other occupation or qualifications, while the flexible nature of their operation can make it possible for operators to combine it with care for children or other dependents. It has also been found that network connections created and maintained by some entrepreneurs, including women, can be mobilized for other mutually advantageous purposes. This research study explored these issues through a questionnaire-based survey of 80 female Thai entrepreneurs. It was shown that the majority of these women started their businesses of their own volition and maintained autonomy over operations. The structure of these businesses is different, therefore, from family-owned businesses which tend and are intended to remain in operation for multiple generations and which have their destiny ultimately controlled by men. Various results of the study are discussed and used to draw conclusions and make recommendations about the management of such businesses in the future.
\end{abstract}

Keywords: Women entrepreneurs, SMEs, Lampang Municipality Area

\section{Introduction}

Entrepreneurialism is recognized as being an important contributory factor in the development of countries and regions, particularly when it is adjudged that linking people and communities better to markets will help solve resource allocation problems. Entrepreneurialism does not suit everybody: it requires not just determination and resilience but also the willingness to consider all relationships as being potential opportunities for making money. However, in some cases it is not necessary for the entrepreneur to be a fully committed and dedicated person aimed at making the venture becomes as large and profitable as possible. In some cases, it is possible for entrepreneurs to begin a venture which is deliberately limited in scope in terms of both time and money. Such ventures are, in developing countries, often associated with women, particularly women who may have some specific income-raising objective to achieve (e.g. meeting a medical or educational expense) or a particular amount of time available (e.g. the length of a contract a migrant worker husband will be occupied in a remote location). This is an aspect not of gender difference among entrepreneurs but in the different routes they follow into entrepreneurial activity and, hence, the market entry decisions they take (Birley, 1988).

In Southeast Asia, according to Coughlin and Thomas (2002), “... women now outnumber men as business owners" and are at the forefront of owning businesses. This is reflected in the speech of Issara (2009), the Minister of Social Development and Human Security, at the 14th Women Leaders' Network (WLN) Meeting, $4^{\text {th }}$ August 2009. He points out that there were approximately 2,500,000 small and medium enterprises (SMEs), which compose $99 \%$ of all enterprises in Thailand and nearly half of the figure were women. Interestingly, women entrepreneurs in Thailand, particularly in SMEs, have been steadily growing in number since 2004 (Issara, 2009). Although most of these businesses flourish in Bangkok, numbers have increased in all parts of the country. This study focuses on one such part of the country, that of the city of Lampang, in the northern region of Thailand. Although it has a long history, Lampang today is best known for its role as a centre of an industrial region in which the mining of clay, stone and lignite is complemented by the more than 200 ceramics factories located there, together with Thailand's largest power and concrete plants. The city acts as a magnet for migrant workers, therefore, particularly in work that is strongly associated with men's work. Industrial opportunities for women are somewhat limited, therefore, meaning a higher incentive to start an entrepreneurial venture as an alternative to mostly low-paid and low-skilled service sector job alternatives. However, knowledge of women's 
entrepreneurial activities in this city is limited and there is scope for exploratory research concerning the scope and number of such women and aiming to obtain some understanding of the type of work they do, their aspirations and the nature of any constraints to their growth.

\section{Literature Review}

Studies of female entrepreneurs have tended to suffer from the focus on supposed gender differentials while undervaluing the importance of economic factors in determining the extent and nature of women's work in this context. Gender, of course, has an important impact upon the economic factors which women may face but evidence suggests it has no particular impact upon the ability or willingness to become an entrepreneur. Family relationships and care for dependents may complicate this situation. Extending research on female entrepreneurs to non-developed countries may require, therefore, more careful consideration not just of the social and economic situation facing women but the different factors and structures evident in such countries (e.g. Lerner, Brush and Hisrich, 1997). It is also important to remember that the differences between women entrepreneurs in this context, while significant, remain less significant than starting social and economic conditions (Morris et al., 2006). It is also necessary to consider the scale of operations, particularly with respect to the type of venture mostly found in the Mekong Region. Policy formation in western countries, for example, is shaped by the desire to create large companies and, potentially therefore, numerous job opportunities. Menzies, Diochon and Gasse (2004), for example, argue that women entrepreneurs may be less likely to found the kinds of business that will be attractive to venture capitalists. At the micro level, the aggregate number of ventures will change not just as macroeconomic conditions encourage more people into the activity but according to other, sometimes less predictable reasons (Mead and Liedholm, 1998). It might also be noted that there is a strand of literature that is critical of the consideration of women entrepreneurs as a whole as recreating, perhaps unintentionally, the subordination of women in society and in the workplace (Ahl, 2006). There is a need, in other words, for new directions in research that do not replicate the conditions being studied but step outside them (Stevenson, 1990). Nevertheless, it remains common to find research that, notwithstanding intentions, seeks to determine why women differ from men and, by extension, what can be done to reduce that difference (e.g. DeMartino and Barbato, 2003). There is, further, an ambivalent element to changes brought about by neoliberalism which, on the one hand brings additional opportunities through the flexibility of capitalist expansion and, on the other hand, punishes those who are in vulnerable positions when entering the period of change (Rich, 2005).

Challenges of Women Entrepreneurship: There are three major types of barriers in female entrepreneurship. Firstly, women are faced with discriminatory socio-cultural values and traditions. Not only women do not enjoy the same business opportunities, but also they are not treated as being equal to men in terms of both social and economic status. Asian women are expected to care for their family members' well-being especially that young children and older adults. Moreover, wives are expected to be skilled at in-house affairs whilst the husbands are experts in business matters (Cheng \& Liao, 1994). Hence, there are usually conflicts between the different roles of wives, mothers, and businesswomen. Also, women often encounter professional challenges including negative stereotypes, inequality and/or discrimination in the workplace. In other words, women who are entrepreneurs everywhere have two jobs. One is the social expectation to be mothers and/ or wives and the other is out of personal or career choice as businesswomen (Kitching, Mishra \& Shu, 2005). The domestic division of labour and time poverty are said to be major barriers to the growth of women's businesses. This often reduces the credibility of women in conducting businesses as well as excluding them from becoming successful entrepreneurs. Secondly, access to information network and assistance could pose a major barrier to women running businesses as women are viewed as lacking in status, network and credibility. It is assumed that a good network positively affects entrepreneurial activity development: however, networking required great effort and is time consuming. Meanwhile, women entrepreneurs prioritize spousal support in order to take care of children and/or attend business meetings. Finally, women entrepreneurs are faced with difficult access to capital as they are assumed to lack knowledge in handling money (Bruni and Poiggo 2004). In spite of the growing number of female entrepreneurs, the share of female entrepreneurship is still significantly low when compared to their participation rate. For example, female entrepreneurs account for approximately 30 percent of the total number of entrepreneurs in the Western world, whereas more than 40 percent of employees are female (Minniti \& Arenius, 2003). Thus, it is important to understand what factors may favour or hinder female entrepreneurship, such as the combination of personal, and social responsibilities and the consequences of these specific barriers. The 
factors that affect the women entrepreneurs in Lampang would be considered as Gender and division of labour, Socialization, religion, social attitude towards women.

Gender and Division of Labour: Gender is generally division of categories, "men" and "women." Through interaction with caretakers, socialization in childhood, peer pressure in adolescence, and gendered work and family roles women and men are socially constructed to be different in behaviour attitudes, and emotions. The gendered social order is based on and maintains these differences. It is the primary status of Thai women to be mothers and housewives and, secondarily, to be wage-earners to support the family financially. Thai women are expected to take-care household duties; child care, household care (cooking, cleaning, fetching wood and water, etc.), nurturing, and remain close to home all of which are outside the cash economy and concentrated around the household, while men are primarily responsible for economic support and contact with the world outside the home. It is wife responsibility to earn for family if in case of any reason the husband cannot earn. Gender inequality manifests common stereotypical attitudes about women and young girls relate to the jobs and duties they perform (typically housework, and professional work). This is known as the gendered division of labour. In Thailand, women continue to exist in roles and relationships that often make them subordinate to men and they are not permitted to take on higher status work. The Thai motto "Women are the rear legs of an elephant" explain about the role of women in Thai society. A man is the foreleg of the elephant and the woman the hind leg, reinforcing the belief that men are to be leaders and women are to follow and care for husband. Woman should do their share of the walking without fault and follow his footsteps, right or wrong. Woman should go with the man as the man move and provide all their support that they can to the man for their family betterment and status in society. Women of Thailand are believed to have the protected life of home and abandon to pursue careers in business (Gilman, 1898).

Social Values: Socialization is a process whereby an individual acquires a personal identity and learns the norms, values, behaviour, and social skills appropriate to his or her social position (The American Heritage, 2005). In Thai society honouring one's elders and returning the favour of upbringing is foremost among the duties of children to their parents, but the kind of support parents expect from daughters and sons is different. Daughters are expected to take care of the family welfare, while sons are expected to bring honour and power to the family. The most widely available way for sons to discharge their duty is to be ordained as Buddhist monks, even if only for a short period. By doing so, they earn the highest favour in the eyes of their parents, as it is believed to bring them to heaven in the next life, and the parents along with them. Buddhism does not allow ordination for women, so to earn a similar favour; women may choose to improve their parents' welfare in their earthly life by working hard to provide them with material comfort. However, girls are expected and trained to be effective housewives, mothers, and service providers. Domestic chores, sibling care, and assisting mother in household responsibilities, prepare her for the world of care taking of future generations. Gentleness, putting others before oneself, sacrifice, soft-spoken and other feminine qualities is encouraged in her upbringing. From the social perspective, women entrepreneurs in the Asian context have some similarities. Asian women in general are viewed as being substandard in business due to the social expectation to take care of families' wellbeing prior to pursuing their own personal wishes. Working women face the challenge of participating in two mismatched activities implying that their business involvement does not reduce their traditional roles as wives.

According to Achraya (2001), women in Nepal also suffer from bias against women because of the cultural and traditional values. The expected behavioural pattern of women which is marked by modesty and lack of expression is often misinterpreted as incompetence and lack of professionalism. In this setting, the transition itself from a "non-professional" approach to a "professional" one is an extra effort for women. In addition, women by themselves find it difficult to interact and discuss issues as equals, because they have been trained to listen, obey and leave decisions to men in the family. Nepalese women are bearing the double burdensome responsibilities of taking care of three generation of family members and also involving in the commercialized career(Achraya, 2001). According to Korabik, "Chinese women like other women are faced with a dual burden of taking care of their families as well as engaging in an entrepreneurial career" (Korabik, 1994).Taiwan is combining its 'Confucian ethic' with its accomplishment as a newly industrialized country by highly promoting education and high skills for women whilst sustaining jobs and family obligations. In Singapore although being an advance country, women are still expected to care for young and old family members. Similar to Chinese women, Japanese women are traditionally assumed to pursue domestic roles as their first priority (Korabik, 1994). 
Religion and Cultural Values: Religion plays a very important role in every culture. Religion is considered an essential pillar of society; it is not only the major moral force of Thai family and community but has also contributed to the moulding of freedom loving, individualistic, and tolerant people for many centuries (Hello Siam, 2002). Buddhism is the national religion of Thailand. Buddhism has great influence over Thai cultures, lifestyles and traditions. Traditionally, a woman's primary role is to be a 'good wife', who lastingly obey and serve on her husband on every count and happily takes good care of their children and household tasks while submitting to others' wishes before their own which is considered as mothers' selflessness. Buddhism does not discriminate against women but it requires men to become monks whilst women should be responsible for economic activity as the consequences of women's sins are considered to be less serve than those men (Andaya, 2002).Women are viewed as weak, passive, obedient, and submissive. The societal complex concept that emerge various constraints and restrictions which are placed on women in the socialization process- restricted mobility, need for family and social acceptability, need for male protection, high value attached to gentleness, submissiveness, and lack of encouragement for initiative and risk taking (Jyoti, 1996). These values imbibed through years of socialization in the male and female psyche in the Thai society, constitute the strongest psycho-social barrier to the strengthening of women's status. Furthermore, dominant religious believers and traditions do not favour women being involved outside activities. According to Jyoti (1996) in business, women have deal with many people and sometimes they have to travel away from their homes such things are not well accepted by society and therefore constitute a major problem for a women entrepreneur.

\section{Research Methodology}

This research is designed as a qualitative study and focuses only on independent women who co-own or own their businesses with a fair amount of decision making power and authority. This is because these groups of women are not only growing in number but also play significant roles in the economy. The research targeted women entrepreneurs from the different sectors of businesses operating in muang (urban) Lampang. Owing to the unavailability of exact numbers of women entrepreneurs' businesses in Lampang municipality records, the population and sample are approximated based on the number of restaurants, retailers, agencies and limited companies in Lampang. There is no data for women entrepreneurs in Lampang municipality's business directories. However, according to the SME officer at Lampang, there are approximately 400 women entrepreneurs, located in seven distinct areas: the bus station area including Big C supermarket; Sanambin area, including Tesco supermarket; Aswin market area; the railway station area; the Doi Prabaht Area; Kadkon Ta and the clock tower area (Department of Business Development of Lampang, 2011). The Yamane equation suggested that, for a population of 400 people, a sample size of 80 would be appropriate.

The Questionnaire: The main method used in this research is the administration of a structured questionnaire, which was designed and formulated in order to ascertain the answers of the study objectives. The study utilized a self-administered questionnaire comprising of both closed ended questionnaire and open ended comments. The questionnaire was developed in English and translated to Thai in order to make it understandable for participants. The questionnaire consists of 4 parts. The first part concerned demographic information, the second part concerned the characteristics of female SME entrepreneurs, the third factors affecting women entrepreneurs and the fourth consisted of open-ended questions which gave respondents the opportunity to add any additional information they felt was pertinent. The questionnaire was translated into the Thai language for the convenience of respondents and Thai language-speaking assistants were engaged to help collect data. Data collection took place from October to December, 2011. The SPSS program was used in subsequent collation and analysis of data.

\section{Results}

Demographic Information: The first section of the questionnaire concerned demographic factors. In terms of age, $7.5 \%$ of respondents were below $20,23.8 \%$ between $21-30,40.0 \%$ from $31-40,21.3 \%$ from 41-50 and $7.5 \%$ over $50 .{ }^{1}$ The respondents were quite mature, therefore. The married category was largest (48.8\%), with $37.5 \%$ single, $10.0 \%$ divorced and $3.8 \%$ widowed. In terms of siblings, $11.3 \%$ reported they were the only child, while $33.8 \%$ were the oldest child in a family of more than one child and $25.0 \%$ the youngest in the family. Finally, $30.0 \%$ reported that they were one of more than four children. The majority of respondents were Buddhist (90.0\%), with smaller numbers of Christians (8.8\%)

\footnotetext{
${ }^{1} \mathrm{~N}$ for this question and all others $=80$.
} 
and Muslims (1.3\%). The sample was quite well-educated compared to the overall population. Only $16.3 \%$ had only primary level education, while $32.5 \%$ had middle school education and the remaining $51.3 \%$ had a more advanced level of education. In terms of income, 51.3\% earned 10-20,000 baht per month, 20. \% earned 20-30,000 baht per month, 16.3\% earned 30-40,000 baht per month and the remainder $(12.5 \%)$ more than 40,000 baht. These figures are all higher than the minimum wage, which suggests that the entrepreneurs as a whole are quite successful.

Characteristics of Women SME Entrepreneurs: Most of the sample opened their business below the age of $30(60.0 \%)$, with $27.5 \%$ doing so between $30-35$ and the remaining $12.5 \%$ from $35-40$. Although the sample was quite mature in age, therefore, they generally began in business quite young. Most of the businesses were small-scale in nature, with $86.3 \%$ having from 1-9 employees, $10.0 \%$ from $10-49$ employees and the remaining $3.8 \%$ with 50 or more employees. The sample of businesses was mostly involved in services (87.5\%) compared to physical products (12.5\%). $23.8 \%$ of businesses were involved with clothing and accessories, $6.3 \%$ in hotels and services, $33.8 \%$ in restaurants and food and the remaining $36.3 \%$ in other areas. Most of the women were part-time managers of their businesses: $11.3 \%$ worked less than 6 hours a week, $42.5 \%$ from $7-10$ hours and $46.3 \%$ more than this amount. For $66.3 \%$ of the sample, this was their first enterprise, with the balance (33.8\%) having operated another business. Most of them started the business themselves (70.0\%); while 15.0\% inherited it from their family, $11.3 \%$ had bought it and $3.7 \%$ other situations.

Table 1: Obstacles Faced in Operating Business; source: original research

\begin{tabular}{|c|c|c|c|c|c|c|}
\hline $\begin{array}{l}\text { Obstacles Faced while Starting } \\
\text { Business }\end{array}$ & n & $\%$ & $\begin{array}{l}\text { Obstacles Now in Running } \\
\text { Business }\end{array}$ & the & $\mathbf{n}$ & $\%$ \\
\hline None & 14 & 17.5 & None & & 24 & 30.0 \\
\hline Question of self-confidence & 10 & 12.5 & Combining family and work life & & 10 & 12.5 \\
\hline Raising capital/finance & 13 & 16.3 & Liquidity/financial problems & & 23 & 28.8 \\
\hline Lack of information/advice & 16 & 20.0 & No time for training/upgrading & & 8 & 10.0 \\
\hline Finding the right contacts & 5 & 6.3 & $\begin{array}{l}\text { Gaining acceptance/respect } \\
\text { society }\end{array}$ & from & 12 & 15.0 \\
\hline Combining family and work life & 21 & 6.3 & Other & & 3 & 3.7 \\
\hline Other & 1 & 1.3 & & & & \\
\hline
\end{tabular}

In terms of obstacles faced by the women entrepreneurs, most faced some problems based in establishing their businesses and also in operating them at the present. As might be expected, it is in the area of finance that problems are commonly observed, which is true from a global perspective. Self-confidence and combining family and work life issues were also observable.

Gender and the Division of Labour: The respondents were presented with six statements in this section in the form of Likert scale questions, with options ranging from 1 (low) to 5 (high) and then averaged. The table below indicates the results in this section.

Table 2: Gender and the Division of Labour; source: original research

\begin{tabular}{lll}
\hline Gender and Division of Labour & Mean $(\bar{X})$ & SD \\
\hline The primary role of a woman is to be a mother and housewife & 3.41 & 1.17 \\
Culturally, women are expected to take care of household duties and child care & 3.50 & 1.13 \\
Men are the primary income earners for the family & 3.15 & 1.22 \\
Women should depend on men and husbands to make a decision & 2.56 & 1.10 \\
Women should follow men's footsteps whether right or wrong & 2.00 & 1.04 \\
House work is for women only & 2.10 & 1.06 \\
Overall & 2.78 & \\
\hline
\end{tabular}

It is evident from these results that the women in the sample recognize the pressures placed on people to conform to a gendered division of roles and responsibilities but are less likely to wish to abide by the implications of such a system.

Social Values: Respondents were next presented with a series of statements relating to social values and again asked to provide opinions via the Likert scales. The results are shown below. 
Table 3: Social values; source: original research

\begin{tabular}{lll}
\hline Social Values & Mean $(\bar{X})$ & SD \\
\hline Culturally, family relatives support one to make independent decisions & 3.88 & 0.89 \\
Girls are socially expected and trained to be effective housewives, mothers and & 3.63 & 0.95 \\
service providers & & \\
Working hard is the duty of men not women & 3.26 & 1.16 \\
Self-reliance and desire for independence is part of one's family values & 3.73 & 1.05 \\
Culturally, families support a woman to make her own decisions & 3.31 & 0.94 \\
Overall & 3.56 & \\
\hline
\end{tabular}

These results indicate, overall, that the sample of respondents rather agrees with these statements about social values. This includes the belief that families will support the individuals to make their own decisions and that self-reliance and desire for independence is a part of family values. At the same time, gender divisions in terms of aspirations and expectations are also evident and this seems to represent something of a contradiction, which is perhaps normal for bourgeois society.

Religion and Cultural Values: Finally, respondents were provided with a series of statements relating to religious and cultural values and again asked to respond by means of the Likert scales provided. The results of this are shown in the table below.

Table 4: Religious and Cultural Values; source: original research

\begin{tabular}{lll}
\hline Religious and Cultural Values & Mean $(\bar{X})$ & SD \\
\hline Culturally, being a good woman revents one from high achievement & 2.61 & 1.14 \\
Obedience prevents one from self-reliance and desire for independence & 2.80 & 1.18 \\
Sons are expected to bring wealth and power to the family & 2.68 & 1.08 \\
Being gentle, putting others before oneself and being polite could prevent one & 3.15 & 1.00 \\
from changing a course of action when plans do not work & & \\
The view that women are viewed as weak, passive, obedient and submissive & 2.75 & 1.23 \\
prevents self-confidence & & \\
By nature, women are less entrepreneurial than men & 2.42 & 1.14 \\
Entrepreneurs are born and not made & 2.55 & 1.26 \\
Culturally, passions and action orientation are regarded as men's qualities & 2.76 & 1.27 \\
Culturally, travelling away from homes is not accepted by one's family & 3.01 & 1.27 \\
Men are more of risk-takers than women are & 2.97 & 1.18 \\
\hline
\end{tabular}

The results here indicate that the women in the sample tended not to agree very strongly with the ideas about religious and cultural values, which are quite conservative in nature. These are indications of changes in society, if it is assumed that people in the past would in fact have agreed with such statements, which of course is far from certain. There is certainly less agreement with these factors than in the previous section, which tends to suggest that the family is considered to be more important than other forces in society (e.g. religious values).

\section{Discussion}

Objective 1: Demographic Factors: The findings are similar to many previous studies, for example it assumed that single and widow women are more successful than married women because married women have lots of obstacles like they have to balance their family life and business but after research, found that most of entrepreneurs are married women and they manage their family life and business. In many other Asian countries like Nepal, India, Vietnamese, it is found that women cannot study, do job or start their business because they have family pressure. They have to take care of their kids, husband and in-laws and do household work also. So they do not have time for any kind of business but according to respondents in Lampang municipality area, it is found that many married women are involved in business. According to the results received the income that they receive from their businesses, many of which require only part-time responsibilities from them, can be quite high. The sample appears to be successful, on the whole.

Objective 2: Characteristics of Women Entrepreneurs in Lampang Municipality Area: It is widely believed that Thai women entrepreneurs have common characteristics which are likely to include a desire for autonomy and independence, with an innovative and assertive personal motivation toward 
earning money. After doing this research, it has become apparent that many of the Lampang women entrepreneurs involved started their own business between the ages of 25-60 and that the business size is not very large, although usually above the micro-level. According to their answers, they can hire 1-9 employees for their businesses and are able to pay them every month. Their businesses tend to be service -oriented rather than product-oriented, including restaurants and other food sector businesses. Mostly the women have been running their businesses for at least five years and after looking their business they help at home also. Many women entrepreneurs in Lampang have created their business by themselves and they have worked hard to get success, usually spending more than 12 hours per day in their business. It is true that doing business is not an easy job for women and they have to face many obstacles, such as finding the right contacts, combining family and work life and other issues. However, they still want to run a business, they want to be independent, they have a need for control and freedom and did not want to work for others, all of which are very strong characteristics of women entrepreneurs.

Objective 3: Factors Affecting Women Entrepreneurs in Lampang Municipality Area: According to the respondents, it is apparent that different age groups of women entrepreneurs have different opinions on gender and the division of labour. More mature respondents tend to have stronger opinions in this area than do the younger entrepreneur respondents. They strongly disagree with women's responsibility being limited to household or domestic work. According to them, mutual work and equal participation is needed in dealing with domestic responsibilities including from the men in the family. However, there is no relationship between age and social values and age and religious or cultural values. Before doing the research, it was assumed that marital status would be affected by religious and cultural values; nevertheless, the research shows that that there is no such relationship between marital status and social, religious and cultural values. It appears that married women are more involved in entrepreneurship than single, widowed or divorced women. Regardless of their religion, Buddhist, Muslim, Christian or Hindu, women seem to be free to do business. There is no restriction from religion and religious beliefs do not affect gender and the division of labour, social values and religious and cultural values because women entrepreneurs in Lampang expressed the same opinions. By contrast, there were some relationships between the size of the venture maintained and opinions about social and cultural factors.

\section{Conclusion}

This study sought to understand characteristics of Thai women entrepreneurs and factors that affect them when running SMEs in Lampang municipality area. Most women involved are Buddhist, married women involved in the service sector, although there are of course many variations. Most women started the business themselves and may have to overcome problems with work and family life balance. It was also the case that the women did recognize that there were some issues involved in terms of the continued gendered division of labour and the asymmetric requirements of women in terms of household work and dependent care. Additional research would be helpful in further examining the similarities and dissimilarities between this sample of women and others also investigated within the Mekong region and elsewhere. This would also help to resolve some of the limitations to this research project in times of limitations on time and space.

\section{References}

Achraya, M. (2001). Impediments for Woman Entrepreneurship Development, UNESCAP, retrieved from: http://www.unescap.org.

Ahl, H. (2006). Why Research on Women Entrepreneurs Needs New Directions. Entrepreneurship Theory and Practice, 30(5), 595-621.

Andaya, B. W. (2002). Localizing the universal: women, motherhood and the appeal of early Theravada Buddhism. Journal of Southeast Asian Studies, 33, 1-30.

Birley, S. (1988). Female Entrepreneurs: Different or Not? Journal of Small Business Management, 2(1), 3237.

Bruni, A. G. \& Poggio, S. (2004). Entrepreneur-Mentality, Gender and Study of Women Entrepreneurs. Journal of Organizational Change Management, 17(3), 256-68.

Cheng, W. Y. \& Liao, L. L. (1993). Women Managers in Taiwan. International Studies of Management and Organization, 23(4), 65-86.

Coughlin, J. H. \& Thomas, A. R. (2002). The Rise of Women Entrepreneurs. Westport, CT: Greenwood Publishing Group, Inc. 
DeMartino, R. \& Barbato, R. (2003). Differences between Women and Men MBA Entrepreneurs: Exploring Family Flexibility and Wealth Creation as Career Motivators. Journal of Business Venturing, 18(6), 815-32.

Department of Business Development of Lampang. (2011). retrieved from http://www.dbd.go.th/mainsite/index.php?id=145 (in Thai).

Gilman, P. C. (1898). A Study of the Economic Relation between Men and Women as a Factor in Social Evolution retrieved

from: http://digital.library.upenn.edu/women/gilman/economics/economics.html.

Hello Siam. (2002). Religion in Thailand. Retrieved from http://www.hellosiam.com/html/thailand/thailand-religion.htm.

Issara, S. (2009). Thai Women in Business: The Rise of Thai Women Entrepreneurs and Their Contribution to Global Trade and Commerce, address given at the 14th Women Leaders' Network (WLN) Meeting, Singapore, retrieved from http://www.apecwln.org/wpcontent/uploads/2009\%20WLN\%20-\%20Issara\%20Somchai\%20\%20Thai\%20Women\%20in\%20Business.pdf.

Jyoti, T. (1996). Factors affecting woman entrepreneurship in small and cottage industries in Nepal: Development corporate agency.

Kitching, B. M., Mishra, R., \& Shu, X. (2005). A Comparative Study of Women in the Business Workplace in India and in China, ABERU Discussion Paper No.16, retrieved from: http://www.buseco.monash.edu.au/units/dru/papers/working-papers-05/1605-kitching.pdf.

Korabik, K. (1994). Managerial Women in the People's Republic of China: Women Managers in a Global Economy. In N. A. D. Izraeli (Ed.), People's Republic of China, Oxford: Basil Blackwell, pp.114-6.

Lerner, M., Brush, C. \& Hisrich, R. (1997). Israeli Women Entrepreneurs: An Examination of Factors Affecting Performance. Journal of Business Venturing, 12(4), 315-39.

Mead, D. C. \& Liedholm, C. (1998). The Dynamics of Micro and Small Enterprises in Developing Countries. World Development, 26(1), 61-74.

Menzies, T. V., Diochon, M. \& Gasse, Y. (2004). Examining Venture-Related Myths Concerning Women Entrepreneurs. Journal of Developmental Entrepreneurship, 9(2), 89-107.

Minniti, M. \& Arenius, P. (2003). Women and Entrepreneurship, in Reynolds, P., M. Camp, and M. Hay. 2002 Global Entrepreneurship Monitor. 2003. Kansas City, MO: The E. M. Kauffman Foundation.

Morris, M. H., Miyasaki, N. N., Watters, C. E. \& Coombes, S. M. (2006). The Dilemma of Growth: Understanding Venture Size Choices of Women Entrepreneurs. Journal of Small Business Management, 44(2), 221-44.

Rich, E. (2005). Young Women, Feminist Identities and Neo-Liberalism. Women's Studies International Forum, 28(6), 495-508.

Stevenson, L. (1990). Some Methodological Problems Associated with Researching Women Entrepreneurs. Journal of Business Ethics, 9(4-5), 439-46.

The American Heritage. (2002). Socialization. In E.D. Hirsch, J.F. Kett \& J. Trefil, eds., The New Dictionary of Cultural Literacy, Boston and New York: Houghton Mifflin. 